\title{
Silicon fertilization and soil water tensions on rice development and yield
}

\author{
Jakeline R. de Oliveira ${ }^{1}$, Marcio Koetz ${ }^{1}$, Edna M. Bonfim-Silva ${ }^{1}$ \& Tonny J. A. da Silva ${ }^{1}$ \\ ${ }^{1}$ Universidade Federal de Mato Grosso/Instituto de Ciências Agrárias e Tecnológicas. Rondonópolis, MT. E-mail: jakeliner.oliveira@hotmail.com \\ (Corresponding author); marciokoetz@yahoo.com.br; embonfim@hotmail.com; tonnyjasilva@hotmail.com
}

Key words:

Oryza sativa

tensiometer

silicon

\begin{abstract}
A B S T R A C T
The cultivation of upland rice (Oryza sativa) in Brazil occurs mainly in the Cerrado, a region with adverse weather conditions. The use of silicon in its cultivation becomes important, since this nutrient provides higher rigidity, lower transpiration and higher resistance to dry spells in rice plants. The objective of the present study was to evaluate the effect of silicon fertilization and soil water tensions on upland rice development and yield in a Cerrado Oxisol. A 5 x 5 fractionated factorial with five soil water tensions $(0,15,30,45$ and $60 \mathrm{kPa})$ and five silicon doses $\left(0,120,240,480\right.$ and $\left.960 \mathrm{mg} \mathrm{dm}^{-3}\right)$ was used, which were distributed in a randomized block design, with four replicates. Plant height, number of tillers, number of panicles, number of grains per panicle, numbers of full and empty grains and percentage of empty grains were evaluated. Silicon fertilization promotes increased tillering in rice plants at the dose of $960 \mathrm{mg} \mathrm{dm}^{-3}$. The numbers of tillers and panicles decreased with the application of silicon up to the doses of 460 and $490 \mathrm{mg} \mathrm{dm}^{-3}$, respectively. The increase in soil water tensions reduced plant height and the number of full grains, and increased the percentage of empty grains of upland rice.
\end{abstract}

\section{Palavras-chave: \\ Oriza sativa tensiômetro silício}

\section{Adubação silicatada e tensões de água no solo no desenvolvimento e rendimento do arroz}

\begin{abstract}
R E S U M O
O cultivo de arroz (Oryza sativa) de terras altas no Brasil ocorre principalmente em área de Cerrado, região que apresenta condições climáticas adversas. A utilização do silício em seu cultivo torna-se importante de vez que este nutriente proporciona maior rigidez, menor transpiração e maior resistência a veranicos em plantas de arroz. No presente estudo, objetivou-se avaliar o efeito da adubação silicatada e tensões de água do solo no desenvolvimento e rendimento de arroz de terras altas em Latossolo Vermelho do Cerrado. Utilizou-se esquema fatorial $5 \times 5$ fracionado com cinco manejos de irrigação baseados nas tensões de água no solo $(0,15,30,45$ e $60 \mathrm{kPa})$ e cinco doses de silício $(0,120,240,480$ e 960 $\mathrm{mg} \mathrm{dm}^{-3}$ ) as quais foram distribuídas segundo delineamento de blocos ao acaso, com quatro repetições. Foram avaliados: altura de plantas, número de perfilhos, número de panículas, número de grãos por panícula, número de grãos cheios e chochos e porcentagem de grãos chochos. Adubação silicatada promove o aumento do perfilhamento em plantas de arroz com a dose de $960 \mathrm{mg} \mathrm{dm}^{-3}$. Ocorreu um decréscimo de produção de perfilhos e número de panículas com a aplicação de silício até as doses de 460 e $490 \mathrm{mg} \mathrm{dm}^{-3}$, respectivamente. $\mathrm{O}$ aumento das tensões de água no solo reduziu a altura e o número de grãos cheios, e aumentou a porcentagem de grãos chochos de arroz de terras altas.
\end{abstract}




\section{INTRODUCTION}

The cultivation of upland rice (Oryza sativa) in Brazil is the most widespread production system in the territory, with production in Mato Grosso, Goiás, Piauí, Maranhão, Pará, Rondônia and Tocantins (MAPA, 2014). Current studies prioritize actions to consolidate the presence of the crop in grain-production systems in Cerrado regions, with satisfactory yields (Crusciol et al., 2012; 2013; Artigiani et al., 2012).

This region is characterized by the predominance of soils with low natural fertility and the occurrence of dry spells that cause water deficiency to the crop (Bastos \& Ferreira, 2010). This factor, along with high atmospheric evapotranspiration demand, causes substantial decreases in rice yield.

Sprinkler irrigation is an alternative to minimize the production problems caused by the dry spells, since it provides stability for the production, which can increase yield and improve grain quality. Among the methods to establish the management of irrigations, the one based on soil water tension has been proved viable in the monitoring of irrigations under the conditions of Latosols (Almeida et al., 2010).

Irrigation, combined with fertilization with chemical elements considered beneficial to crops, has become common among farmers. Silicon, despite not being physiologically essential to plants, promotes various direct and indirect benefits, such as increase in cell wall resistance, regulation of evapotranspiration and increase in photosynthetic rate, besides improving leaf architecture and promoting reduction in the incidence of diseases, especially fungal (Lima et al., 2011), particularly for monocotyledonous plant like rice.

The use of silicon in Brazil began to be widespread after its inclusion as a micronutrient (Lima et al., 2011). Silicon oxide (Lima et al., 2011) is the most abundant mineral in the soils and is the base of the structure of most clay minerals. However, considering the advanced degree of weathering of tropical soils, the available contents of silicon are low and this element is basically found in forms non-available to plants (Fageria et al., 2011a).

According to studies conducted to evaluate the use of silicon in agriculture, the rice crop shows increase in the number of leaves and in the number of spikelets per panicle, higher plant height and higher content and accumulation of silicon in plant shoots (Artigiani et al., 2012; Yogendra et al., 2014).

In this context, this study aimed to evaluate the effect of silicon fertilization and soil water tensions on the development and yield of upland rice cultivated in a Cerrado Oxisol.

\section{Material ANd Methods}

The experiment was carried out from June to October 2014, in a greenhouse. The soil was collected in the layer of $0-0.20 \mathrm{~m}$ of Oxisol of sandy loam texture (EMBRAPA, 2013), in an area under Cerrado vegetation. The soil was sieved through a $2-\mathrm{mm}$ grid for chemical and granulometric analysis, according to the methodology proposed by EMBRAPA (1997) (Table 1) and sieved through a 4-mm grid for the filling of the pots.

Liming was performed in order to increase base saturation to $50 \%$. Acidity was corrected by applying dolomitic limestone $(\mathrm{RNV}=80.3 \%)$ in the soil, which was incubated for 30 days with water content at $60 \%$ of field capacity.

Five irrigation managements based on soil water tensions $(0,15,30,45$ and $60 \mathrm{kPa})$ were evaluated in combination with five silicon doses $\left(0,120,240,480\right.$ and $\left.960 \mathrm{mg} \mathrm{dm}^{-3}\right)$ in a response surface study based on a central composite design modified from a 5 x 5 fractionated factorial, according to Littel \& Mott (1975), distributed in randomized blocks, with four replicates. Thus, the 13 combinations of soil water tensions and silicon doses, respectively in $\mathrm{kPa}$ and $\mathrm{mg} \mathrm{dm}^{-3}$, were: $0-0$; 0-240; $0-960 ; 15-120 ; 15-480 ; 30-0 ; 30-240 ; 30-960 ; 45-120 ; 45-480$; 60-0; 60-240 and 60-960. Each experimental unit consisted of one plastic pot with volume of $8 \mathrm{dm}^{3}$ and one tensiometer.

Basal fertilization was performed using $200 \mathrm{mg} \mathrm{dm}^{-3}$ of $\mathrm{P}_{2} \mathrm{O}_{5}$ as single superphosphate and $80 \mathrm{mg} \mathrm{dm}^{-3}$ of $\mathrm{K}_{2} \mathrm{O}$ as potassium chloride. The nitrogen dose of $200 \mathrm{mg} \mathrm{dm}^{-3}$ was divided into two equal applications, one at 15 days after sowing and the other one at 30 days after sowing.

The silicon source used in the experiment was silicon dioxide $\left(\mathrm{SiO}_{2}\right)$ with $95 \%$ of silicon. The doses corresponding to the treatments $\left(0,120,240,480\right.$ and $960 \mathrm{mg} \mathrm{dm}^{-3}$ of Si) were incorporated to the soil at planting.

Sowing was performed on June 18, 2014, by planting ten seeds per pot, at a depth of $3 \mathrm{~cm}$. Thinning was performed ten days after emergence (DAE), leaving four plants per pot.

Irrigation management was performed using the soil-water retention curve, determined in the layer of 0-0.20 m (Figure 1). Irrigations were manually performed and calculated in order to increase the values of soil water tension to that of field capacity $(5 \mathrm{kPa})$ for the treatments, when the established tensions (treatments) were reached. For the treatment in which soil water tensions were equal to $0 \mathrm{kPa}$, a water depth of approximately $2 \mathrm{~cm}$ was maintained on the soil surface along the experiment.

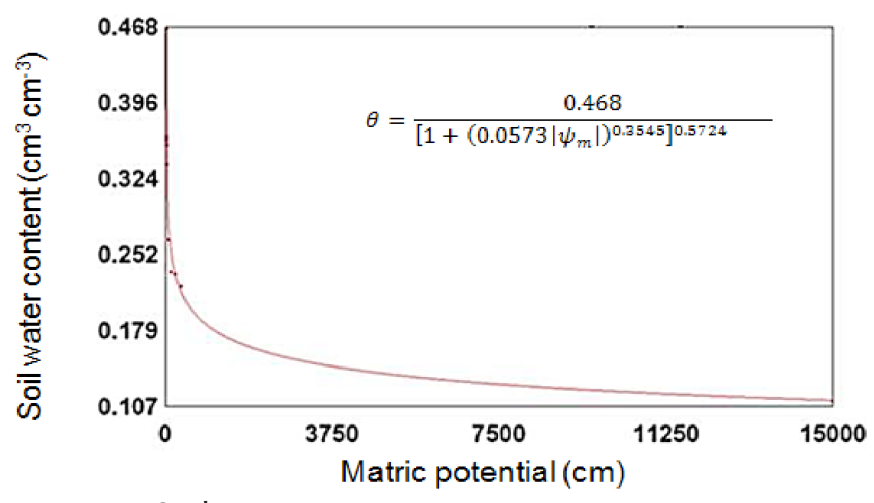

Figure 1. Soil-water retention curve

Table 1. Chemical and granulometric characterization of a sample of Oxisol collected in the layer of 0-0.20 m

\begin{tabular}{|c|c|c|c|c|c|c|c|c|c|c|c|c|c|}
\hline \multirow{2}{*}{$\begin{array}{c}\mathrm{pH} \\
\mathrm{CaCl}_{2}\end{array}$} & $\mathbf{P}$ & $\bar{K}$ & $\mathrm{Ca}$ & $\mathrm{Mg}$ & $\mathrm{H}$ & $\overline{A l}$ & SB & CEC & \multirow{2}{*}{$\begin{array}{l}\mathbf{V} \\
\%\end{array}$} & \multirow{3}{*}{$\begin{array}{c}0 \mathrm{M} \\
\mathrm{g} \mathrm{dm}^{-3}\end{array}$} & \multirow{2}{*}{\multicolumn{3}{|c|}{$\frac{\text { Silt }}{\mathrm{g} \mathrm{kg}^{-1}}$}} \\
\hline & \multicolumn{2}{|c|}{$\left(\mathrm{mg} \mathrm{dm}^{-3}\right)$} & \multicolumn{6}{|c|}{$\mathrm{cmol}_{\mathrm{c}} \mathrm{dm}^{-3}$} & & & & & \\
\hline 4.1 & 2.4 & 28 & 0.3 & 0.2 & 4.2 & 1.1 & 0.6 & 5.9 & 9.8 & & 549 & 84 & 367 \\
\hline
\end{tabular}

SB - Sum of bases; CEC - Cation exchange capacity; V - Base saturation; OM - organic matter 
At 121 days after rice sowing, the following variables were evaluated: plant height (from the soil surface to the tip of the panicle in all the plants in the experimental plots); number of tillers (counting all the tillers in the plot); number of panicles (counting the number of panicles in each experimental unit at harvest); number of grains per panicle (number of grains randomly collected in five panicles of each plot); number of full (whole grain) and empty (sterile) grains (counting five panicles per plot); and percentage of empty grains (ratio between the number of empty grains and the total number of grains in five panicles per plot).

The results were subjected to statistical analysis using the program SAS - System for Windows (SAS Institute, 2002), with analysis of variance and regression test at 0.05 probability level.

\section{Results AND Discussion}

There was no interaction between silicon fertilization and soil water tensions for any of the analysed variables. However, there was isolated effect of the factors silicon fertilization and soil water tensions for the analysed variables (Table 2).

There was isolated effect of the soil water tensions on plant height, which fitted to the quadratic regression model (Figure 2) and showed the lowest value at the tension of $59 \mathrm{kPa}$. The maximum plant height $(95.37 \mathrm{~cm})$ was obtained at the soil water tension of $0 \mathrm{kPa}$.

The decrease in soil water content led to lower height in the plants subjected to the highest soil water tensions, with a difference of $25.77 \mathrm{~cm}$ between the tensions of 0 and $60 \mathrm{kPa}$. These results are similar to those obtained by Zou et al. (2007),

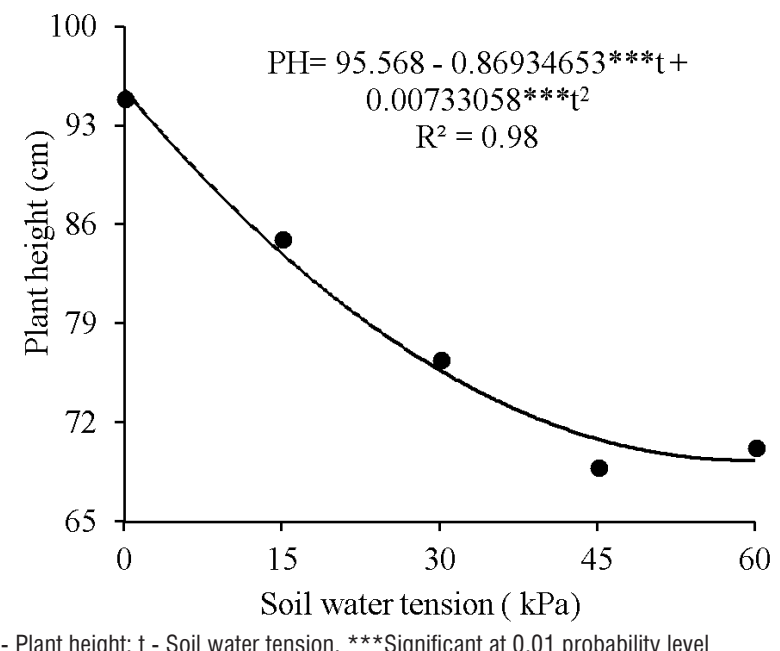

Figure 2. Plant height of rice subjected to soil water tensions in a Cerrado Oxisol who also reported a negative correlation between water deficit and height of rice plants, with reductions of up to $12.5 \mathrm{~cm}$ in plant height. In the present study, the highest difference in plant height may be due to the restrictive conditions imposed by the volume of the pots, which intensified the effects of the treatments.

Terra et al. (2013) and Crusciol et al. (2013) also showed that rice plants subjected to water stress along the cycle reduce their heights. With the increase in water tensions, there was water deficit in the soil, close to the roots; thus, the stomata close, in order to reduce vapor flow and transpiration. Then, there is a decrease in the absorption of water and nutrients by the roots and, consequently, plant height is reduced (Andrade et al., 2002).

Silicon doses had significant effect on the number of tillers and panicles, which fitted to the quadratic regression model (Figure 3A and B). Rice plants showed the lowest tillering (25.5) at the silicon dose of $460 \mathrm{mg} \mathrm{dm}^{-3}$ and, for the number of panicles, the lowest values were obtained at the silicon dose of $490.34 \mathrm{mg} \mathrm{dm}^{-3}$. This similar behavior between the numbers of tillers and panicles occurs because the number of panicles is directly related to the number of tillers, since panicles originate from the elongation of tillers (Santos et al., 2006).

The negative effects of silicon on tillering and on the number of panicles was possibly due to the higher absorption of silicon and lower absorption of phosphorus and nitrogen, favored by the chemical similarity with phosphorus $\left(\mathrm{H}_{2} \mathrm{PO}_{4}^{-}\right)$ (Tokura et al., 2011) and by the competition for absorption sites of nitrogen $\left(\mathrm{NO}_{3}^{-}\right)$(Wallace, 1989$)$ with silicate $\left(\mathrm{H}_{3} \mathrm{SiO}_{4}^{-}\right)$. Thus, at the doses of 460 and $490 \mathrm{mg} \mathrm{dm}^{-3}$, there may have been greater absorption of silicon and lower absorption of these two elements, which are essential for tillering and panicle formation.

These results corroborate those reported by Stocco et al. (2010), who observed reduction in the number of tillers of grasses with the increase in the application of silicates, and those reported by Mauad et al. (2003), who concluded that there was no increase in grain yield or dry matter production, studying different doses of silicates on rice production.

Yasari et al. (2012), studying rice plant density and silica application, observed an increase of $11.6 \%$ in the total number of tillers and $14.2 \%$ in the number of tillers per plant, with the application of $250 \mathrm{~kg} \mathrm{ha}^{-1}$ of pure silica. The different results in the present study may be due to the use of high silicon doses, since the dose promoting the lowest tillering $\left(460 \mathrm{mg} \mathrm{dm}^{-3}\right)$ is approximately twice the dose used by the previously mentioned authors.

Table 2. F values and their respective significances obtained in the analysis of variance for the variables: plant height $(\mathrm{PH})$, number of tillers (NT), number of panicles (NP), number of grains per panicle (NGP), number of full grains (NFG), number of empty grains (NEG) and percentage of empty grains (\%EG) as a function of soil water tensions and silicon doses

\begin{tabular}{|c|c|c|c|c|c|c|c|}
\hline Source of variation & $\mathrm{PH}$ & NT & NP & NGP & NFG & NEG & $\%$ EG \\
\hline Soil water tension $(\mathrm{T})$ & $167.18^{\star \star}$ & $8.68^{\star \star}$ & $5.69 *$ & $5.8^{\star}$ & $18.55^{\star \star}$ & $10.78 * \star$ & $5.49 *$ \\
\hline Silicon doses (S) & $0.12^{\text {ns }}$ & $4.10^{*}$ & $5.36^{\star}$ & $0.04^{\mathrm{ns}}$ & $0.34^{\mathrm{ns}}$ & $0.06^{\text {ns }}$ & $0.67^{\mathrm{ns}}$ \\
\hline $\mathrm{T} \times \mathrm{S}$ & $0.87^{\mathrm{ns}}$ & $0.19^{\text {ns }}$ & $0.21^{\mathrm{ns}}$ & $0.23^{\text {ns }}$ & $0.96^{\text {ns }}$ & $0.88^{\text {ns }}$ & $1.45^{\mathrm{ns}}$ \\
\hline Mean & 79.44 & 27.25 & 23.19 & 129.14 & 452.00 & 193.71 & 29.92 \\
\hline $\mathrm{CV}_{\mathrm{T}}(\%)$ & 6.63 & 12.75 & 10.59 & 20.29 & 21.11 & 35.02 & 25.95 \\
\hline $\mathrm{CV}_{\mathrm{S}}(\%)$ & 14.15 & 15.32 & 10.62 & 21.61 & 25.01 & 43.54 & 35.6 \\
\hline $\mathrm{CV}_{\mathrm{TXS}}(\%)$ & 5.95 & 12.66 & 10.26 & 20.80 & 21.74 & 37.69 & 26.08 \\
\hline
\end{tabular}

${ }^{n s}$ Not significant; ${ }^{* *},{ }^{*}$ Significant at 0.01 and 0.05 probability level, respectively 

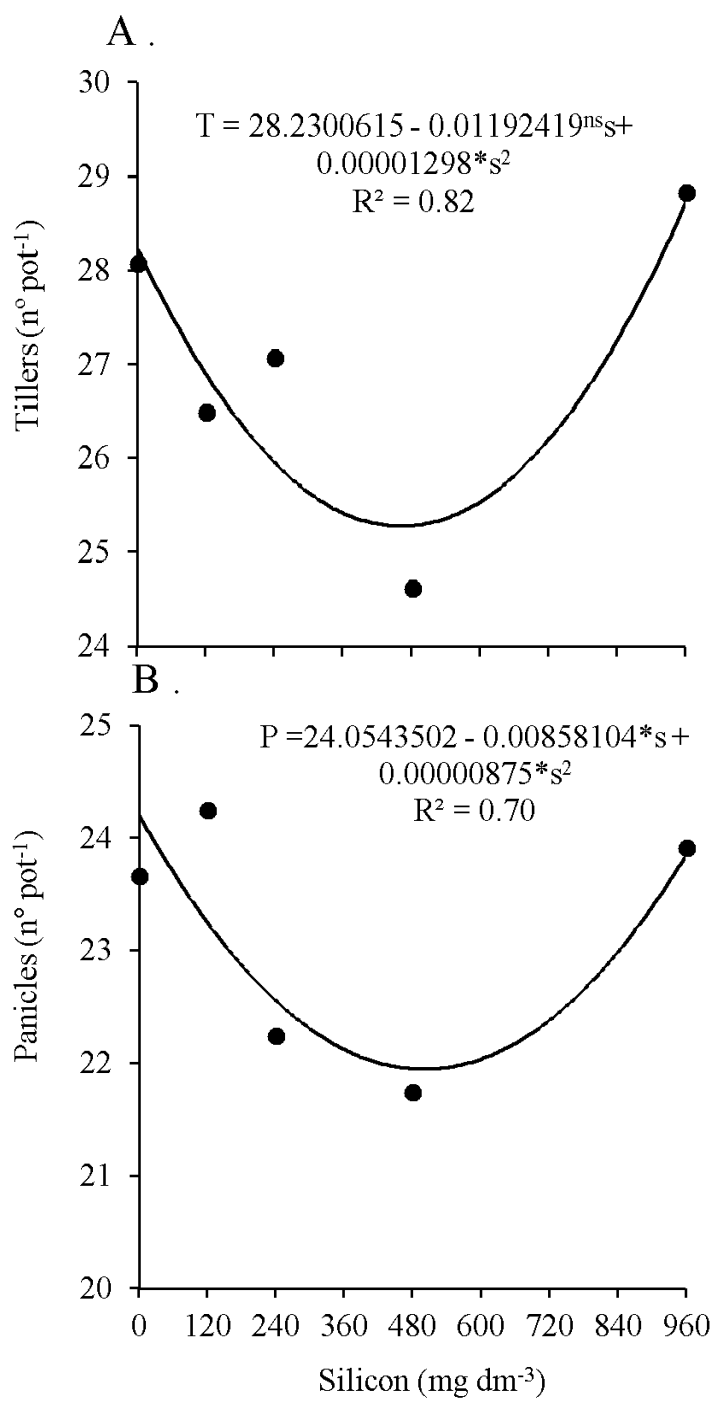

T - Tillers, P - Panicles; $\mathrm{s}$ - Silicon. *Significant at 0.05 probability level; nsNot significant Figure 3. Number of tillers (A) and number of panicles (B) of rice plants subjected to silicon fertilization in a Cerrado Oxisol

There was significant effect of soil water tensions on the number of grains per panicle, which fitted to the quadratic regression model (Figure 4).

The soil water tension of $24.9 \mathrm{kPa}$ promoted 141.7 grains per panicle. These results corroborate those reported by Mauad

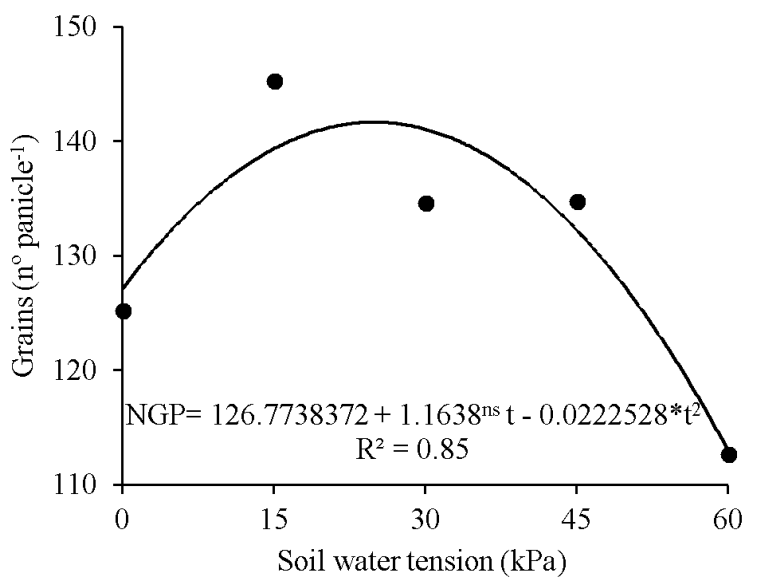

NGP - Number of grains per panicle, $\mathrm{t}$ - Soil water tension; * Significant at 0.05 probability level; " ns Not significant

Figure 4. Number of grains per panicle of rice plants subjected to soil water tensions in a Cerrado Oxisol

et al. (2011), who observed that tensions above $25 \mathrm{kPa}$ caused reduction in the values of rice production components. These authors justified that the decrease in water availability to plants, due to the increase in soil water tensions, reduced plant growth and development, leading to lower formation of grains.

The results obtained in the present study are also consistent with those obtained by Stone et al. (1986), who observed that soil water tensions above $25 \mathrm{kPa}$ caused reduction in the number of rice grains. In both excess and deficiency of water, the water stress caused by soil water tensions reduces the absorption of all the macronutrients in the soil. The contact between ions and roots is different according to the nutrient; nitrogen, calcium and magnesium, through mass flow, while phosphorus and potassium, through diffusion. Regardless of the form of the ion-root contact, the ion must be in the soil solution for the occurrence of absorption (Mauad et al., 2011).

Heinemann \& Stone (2009) reported yield reduction in rice plants subjected water stress, in the period before flowering, which led to lower number of grains per panicle; this may have occurred in the present study, in which rice plants were subjected to irrigation depth treatments still in the vegetative period and remained under these treatments until the harvest.

For the number of full grains and percentage of empty grains, there was an isolated effect of soil water tensions (Figure 5A and C). Soil water tensions had significant effect
A .

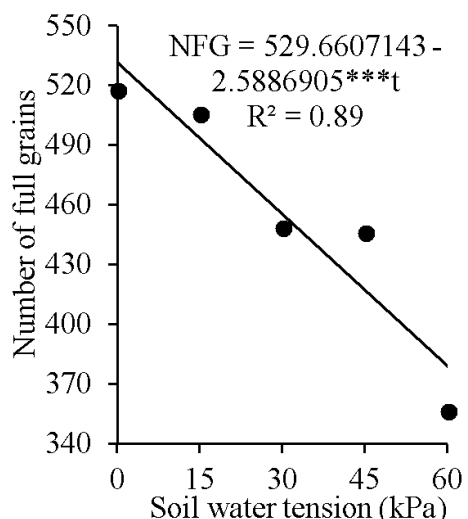

B.

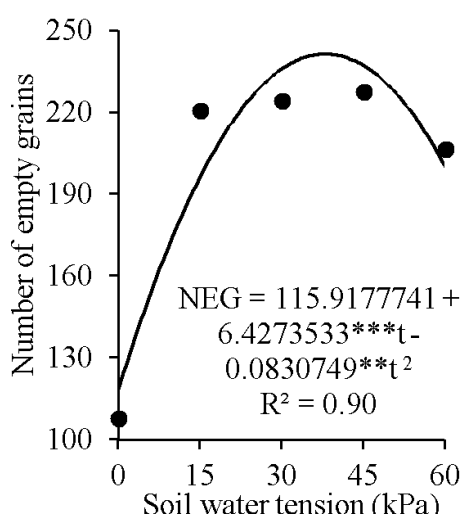

C.

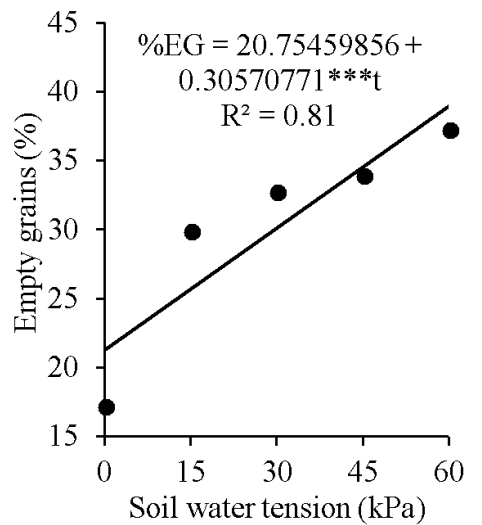

NFG - Number of full grains; NEG - Number of empty grains; \%EG - Percentage of empty grains; $t$ - Soil water tension; ***, ** Significant at 0.01 and 0.10 probability level, respectively Figure 5. Number of full grains (A), number of empty grains (B) and percentage of empty grains (C) of rice plants subjected to soil water tensions in a Cerrado Oxisol 
on the number of empty grains, which fitted to the quadratic regression model (Figure 5B). The highest number of empty grains (241.6) was estimated at the soil water tension of $38 \mathrm{kPa}$.

This may have occurred because, during the reproductive period, when there is meiosis of spore mother cells for fertilization, the lack of water causes sterility or malformation of grains, with reflex in yield (Fageria et al., 2011b). Stone et al. (1984), also under greenhouse conditions, observed that water deficiency reduced the number of spikelets with grains per panicle, grain weight and grain production, and increased the percentage of empty spikelets in rice plants.

The number of full grains decreased by $30 \%$ with the increase in soil water tensions, while the percentage of empty grains increased linearly by $46.91 \%$, in the comparison between the lowest $(0 \mathrm{kPa})$ and the highest $(60 \mathrm{kPa})$ soil water tensions. Although the cultivar used in the experiment is intended for rainfed cultivation, it has characteristics inherent to rice plants, such as root cortex formed by cells with intracellular space called aerenchyma, which are specialized structures that store oxygen for the consumption by root cells. These structures form channels connecting root, stem and leaf, and allow the survival of the plant even in flooded environments (Guimarães et al., 2002).

The lower water availability promoted by the tension of 60 $\mathrm{kPa}$ inhibited plant growth. Consequently, it can be inferred that there was a reduction in the production of assimilates that would be directed to grain filling (Guimarães et al., 2011), which justifies the lower number of full grains and higher percentage of empty grains in this treatment at the highest tensions studied.

Thus, other authors have also reported that rice plants subjected to different levels of water stress reduced grain production (Crusciol et al., 2013; 2012; Heinemann \& Stone, 2009), and emphasized the importance of water supply for grain formation and quality improvement.

\section{Conclusions}

1. The highest number of tillers was obtained with the silicon dose of $960 \mathrm{mg} \mathrm{dm}^{-3}$ and the highest number of panicles was obtained in the absence of silicon fertilization.

2. The soil water tension of $25 \mathrm{kPa}$ promotes the highest number of grains per panicle in upland rice plants.

3. The increase in soil water tension reduces plant height and the number of full grains, and increases the percentage of empty grains of upland rice.

\section{Literature Cited}

Almeida, A. S.; Araújo, F. S.; Souza, G. S. Determinação da curva parcial de retenção de água de um Latossolo Vermelho por tensiometria. Scientia Plena, v.6, p.1-5, 2010.

Andrade, A. P.; Silva, I. F.; Pereira, I. E.; Guimarães, M. A. M. Efeito do estresse hídrico na emissão/abscisão de estruturas reprodutivas do algodoeiro herbáceo cv. CNPA 7H. Revista Brasileira de Engenharia Agrícola e Ambiental, v.6, p.21-27, 2002. http://dx.doi. org/10.1590/S1415-43662002000100005
Artigiani, A. C. C. A.; Crusciol, C. A. C.; Arf, O.; Alvarez, R. C. F.; Nascente, A. S. Produtividade e qualidade industrial do arroz de terras altas em função da disponibilidade hídrica e adubação. Pesquisa Agropecuária Tropical, v.42, p.340-349, 2012. http:// dx.doi.org/10.1590/S1983-40632012000300011

Bastos, L. M.; Ferreira, I. M. Composições fitofisionômicas do bioma Cerrado: Estudo sobre o subsistema de Vereda. Espaço em Revista, v.12, p.99-108, 2010.

Brasil. Decreto $N^{\circ} 2954$. Aprova o regulamento da lei no 6894 de 16 de janeiro de 1980, que dispõe sobre a inspeção e fiscalização da produção e do comércio de fertilizantes, corretivos, inoculantes ou biofertilizantes destinados à agricultura, e dá outras providências. Normas jurídicas (Texto Integral)-DEC 004954, 14 jan., 2004. 27p.

Crusciol, C. A. C; Soratto, R. P.; Nascente, A. S.; Arf, O. Root distribution, nutrient uptake, and yield of two upland Rice cultivars under two water regimes. Agronomy Journal, v.105, p.237-247, 2013. http://dx.doi.org/10.2134/agronj2012.0298

Crusciol, C. A. C.; Toledo, M. Z.; Arf, O.; Cavariani, C. Water supplied by sprinkler irrigation system for upland rice seed production. Bioscience Journal, v.28, p.34-42, 2012.

EMBRAPA - Empresa Brasileira de Pesquisa Agropecuária. Centro Nacional de Pesquisa de Solos. Manual de métodos de análise de solo/Centro Nacional de Pesquisa de Solos. 2.ed. Rio de Janeiro: EMBRAPA, 1997. 212p.

EMBRAPA - Empresa Brasileira de Pesquisa Agropecuária. Sistema brasileiro de classificação de solos 3.ed. Brasília: EMBRAPA, 2013. 353p.

Fageria, N. K,; Baligar, V. C.; Jones, C. A. Growth and mineral nutrition of field crops. Boca Raton: CRC Press, 2011a. 640p.

Fageria, N. K.; Moreira, A.; Coelho, A. M. Yield and yield components of upland rice as influenced by nitrogen sources. Journal of Plant Nutrition, v.34, p.361-370, 2011b. http://dx.doi.org/10.1080/019 04167.2011 .536878

Guimarães, C. M.; Fageria, N. K.; Barbosa Filho, M. P. Como a planta de arroz se desenvolve. Arquivo do Agrônomo. Piracicaba: Potafós, v.13, 2002. 12p.

Guimarães, C. M.; Stone, L. F.; Oliveira, J. P.; Rangel, P. H. N.; Rodrigues, C. A. P. Sistema radicular do arroz de terras altas sob deficiência hídrica. Pesquisa Agropecuária Tropical, v.41, p.126134, 2011. http://dx.doi.org/10.5216/pat.v41i1.8460

Heinemann, A. B.; Stone, L. F. Efeito da deficiência hídrica no desenvolvimento e rendimento de quatro cultivares de arroz de terras altas. Pesquisa Agropecuária Tropical, v.39, p.134-139, 2009.

Lima, M. A.; Castro, V. F.; Vidal, J. B.; Enéas Filho, J. Aplicação de silício em milho e feijão-de-corda sob estresse salino. Revista Ciência Agronômica, v.42, p.398-403, 2011. http://dx.doi. org/10.1590/S1806-66902011000200019

Littell, R. C.; Mott, G. O. Assisted design and analysis of response surface experiments in agronomy. Soil and Crop Society of Flórida Proceedings, v.32, p.94-97, 1975.

MAPA - Ministério da Agricultura, Pecuária e Abastecimento. Cultura do arroz. http://www.agricultura.gov.br/vegetal/culturas/arroz. 12 Nov. 2014.

Mauad, M.; Crusciol, C. A. C.; Grassi Filho, H. Produção de massa seca e nutrição de cultivares de arroz de terras altas sob condição de déficit hídrico e adubação silicatada. Semina: Ciências Agrárias, v.32, p.939-948, 2011. http://dx.doi.org/10.5433/1679$0359.2011 \mathrm{v} 32 \mathrm{n} 3 \mathrm{p} 939$ 
Mauad, M., Grassi Filho, H., Crusciol, C. A. C., Corrêa, J. C. Teores de silício no solo e na planta de arroz de terras altas com diferentes doses de adubação silicatada e nitrogenada. Revista Brasileira de Ciencia do Solo, v.27, p. 867-873, 2003. http://dx.doi.org/10.1590/ S0100-06832003000500011

Santos, A. B. dos; Stone, L. F.; Vieira, N. R. de A. A cultura do arroz no Brasil. 2.ed. Santo Antônio de Goiás: Embrapa Arroz e Feijão, 2006. 8p.

SAS Iinstitute. SAS: User's guide: statistics. 9.ed. Cary: SAS Institute, 2002. 943p.

Stocco, F. C.; Passos, R. R.; Andrade, F. V.; Reis, E. F.; Lima, J. S. S.; Santos, D. A.; Machado, R. V. Uso de escórias de siderurgia na produção de matéria seca e perfilhamento de duas gramíneas do gênero Brachiaria em um Latossolo Vermelho-Amarelo. Bioscience Journal, v.26, p.240-248, 2010.

Stone, L. F; Libardi, P. L.; Reichardt, K. Deficiência hídrica, vermiculita e cultivares. Efeito na produtividade do arroz. Pesquisa Agropecuária Brasileira, Brasília, v.19, p.695-707, 1984.

Stone, L. F.; Moreira, J. A. A.; Silva, S.C. Tensão da água do solo e produtividade do arroz. Goiânia: Embrapa CNPAF, 1986. 6p. Comunicado Técnico, 19

Terra, T. G. R.; Leal, T. C. A. B.; Borém, A.; RangeL, P. H. N. Tolerância de linhagens de arroz de terras altas à seca. Pesquisa Agropecuária Tropical, v.43, p.201-208. 2013. http://dx.doi.org/10.1590/S198340632013000200013
Tokura, A. M.; Furtini Neto, A. E.; Carneiro, L. F.; Curi, N.; Santos, J. Z. L.; Alovisi, A. A. Dinâmica das formas de fósforo em solos de textura e mineralogia contrastantes cultivados com arroz. Acta Scientiarum, Agronomy, v.33, p.171-179, 2011. http://dx.doi. org/10.4025/actasciagron.v33i1.1435

Yasari, E.; Yazdpoor, H.; Kolhar, H. P.; Mobasser, H. R. Effects of plant density and the application of silica on seed yield and yield components of rice (Oryza sativa L.). International Journal of Biology, v.4, p.46, 2012. http://dx.doi.org/10.5539/ ijb.v4n4p46

Yogendra, N. D.; Kumara, B. H.; Chandrashekar, N.; Prakash, N. B.; Anantha, M. S.; Jeyadeva, H. M. Effect of silicon on real time nitrogen management in a rice ecosystem. African Journal of Agricultural Research, v.9, p.831-840. 2014. http://dx.doi. org/10.5897/AJAR12.1841

Wallace, A. Relationships among nitrogen, silicon, and heavy metal uptake by plants. Soil Science, v.147, p.457-460, 1989. http:// dx.doi.org/10.1097/00010694-198906000-00019

Zou, G. H.; Liu, H. Y.; Mei, H. W.; Liu, G. L.; Yu, X. Q.; Li, M. S.; Wu, J. H.; Chen, L.; Luo, L. J. Screening for drought resistance of rice recombinant inbred populations in the field. Journal of Integrative Plant Biology, v.49, p.1508-1516, 2007. http://dx.doi. org/10.1111/j.1672-9072.2007.00560.x 